\title{
CLOWNING ON THE PULPIT? \\ CONTOURS OF A COMIC VISION ON PREACHING ${ }^{1}$
}

\author{
Johan Cilliers \\ Faculty of Theology \\ Stellenbosch University
}

\begin{abstract}
This paper revisits the concept of the preacher as clown, tracing some aspects of the basic philosophy and history behind this somewhat unconventional understanding of the ministry. Attention is given to aspects such as the disruptive effect that the presence of a clown or jester can have on normative discourse, the role of scripture in attaining speech that is subversive to the status quo, and the ethical implications of such a mode of preaching. The theological background for this is explained in terms of the image of a vulnerable God.
\end{abstract}

Keywords: Preaching, Power, Vulnerabilty, Subversion

\section{An unconventional Image of Preaching?}

Most preachers operate from the basis of a certain self-understanding of their identity as preachers; they carry with them a picture of what, according to them, preachers ought to be and do - images that profoundly influence the patterns and practices of their ministry. According to Long, "preachers have at least tacit images of the preacher's role, primary metaphors that not only describe the nature of the preacher but also embrace by implication all the other crucial aspects of the preaching event" (1989:24). He identifies three such "controlling images" or "master metaphors" that have formed the contours within which the majority of preachers have understood their identity in recent years, namely that of the preacher as herald, as pastor and as storyteller (1989:24). Long prefers a fourth image or metaphor, which incorporates the positive elements of the three metaphors mentioned, namely that of the preacher as witness (1989:42).

Of course, there are more than just three or four images that could capture the essence and identity of preaching, and most of the time more than one image is needed to describe a certain ministry within a specific context. In this paper a somewhat unconventional, but not unfamiliar, image is revisited, namely that of the preacher as clown or jester. ${ }^{2}$

Many homileticians ${ }^{3}$ have traced the roots of this metaphor back to Paul's description of the foolishness of preaching in his letters to the Corinthians, for example, when he states: "For the message of the cross is foolishness to those who are perishing, but to us who are being saved it is the power of God... For since, in the wisdom of God, the world did not know God through wisdom, God decided, through the foolishness of our proclamation, to save those who believe." (1 Corinthians 1:18,21) And later on, in the same vein: "I think

\footnotetext{
Edited version of a paper delivered at the eighth international conference of the Societas Homiletica, held in Copenhagen, Denmark, 19-25 June 2008.

2 Traditionally the clown is linked to the circus, and the jester to the court. Although this distinction is kept in mind in this article, the terms are used interchangeably, focusing on the elements that characterize both these modes of comic expression. Cf. also 2 below.

3 For example, Campbell (2008:1-19); Cilliers (2004:3-5); Grözinger (2008:96), etc.
} 
that God has exhibited us apostles as last of all, as though sentenced to death, because we have become a spectacle to the world, to angels and to mortals. We have become fools for the sake of Christ..." (1 Corinthians 4:9-10).

Apparently the church and its preaching have understood themselves to be "fools for Christ" from the very beginning. The preaching of the church is not necessarily well received, but has often been evaluated as scandalous and nonsensical, as laughable and absurd (cf. Cilliers 2004:3-4). The remarkable fact is that the church has understood herself (and even her Christ; cf. 2.4 below) to be comical in the eyes of the world, and has been evaluated as such, especially in times of trial and suffering, in periods of uncertainty and liminality. This image of the church and preaching being a fool or clown seems to come to the fore when the church is vulnerable and without power, when its message seems to have no impact, and its very existence deemed to be ludicrous. On the other hand, this image seems to fade away and is seen as redundant during periods when the church has power, and fits in with political and social structures. It would indeed be a fair question to ask whether the church should not revisit this image in a present period of secularization and so-called post-Christianity (cf. Cox 1969:141).

The comic vision on the church, and specifically the image of the church and preaching as a clown, has a rich history, also finding its way into the art world (for instance, in the paintings of Chagall and Picasso). Authors such as Kierkegaard, Heinrich Böll, Dostoevsky ${ }^{4}$ and others have used it in connection with the church and the life of faith. Kierkegaard, for instance, wrote voluminously about the connection between humour and religion, and did not hesitate to call humour the incognito of true religiosity and even stated as a rule without exception: the wiser a human being becomes, the more he or she will discover the comical (1959:648, 692).

When we look at some of the great exponents of Reformed theology (Calvin, Schleiermacher, Barth, etc.), we find that the comic vision is also not something foreign to this tradition (Theron 1996:218). As a matter of fact, it is an image that links meaningfully to certain theological topoi within this tradition, for instance, the role of the church as alien and temporary sojourner in this world (cf. 1 Peter 2:11). The irony of the church as "being too early for heaven and too late for the earth" (Noordmans 1980:29) seems to be inescapable. Like a clown, the church does not fit in. Its position "between the times" remains rather precarious, and for some hilarious.

The tendency to bypass this image in favour of others could, however, also be linked to the real possibility that it can be misunderstood and misused. The terms "clown" and "comic" could be misunderstood to mean something superficial and frivolous. Clowning on the pulpit could deteriorate into a liturgical circus. But that is clearly not the intention here; on the contrary, these metaphors carry within them the potential of opening up profound meaning concerning life in general and preaching in particular. The comic has to do with more than the funny. ${ }^{5}$ It is a perspective on life which is also of great value for the act of preaching. We now take a closer look at this.

For a summary of their ideas, cf. Faber 1971:97 f.

Cf. Theron (1996:211) in this regard: "One can of course try to distinguish between the comical and the humorous and reserve the former for something frivolous and the latter for something very profound, but that does not correspond to general usage. In common parlance, but also in scientific studies, especially in the English-speaking world, no clear-cut distinctions are made between concepts like humour, comedy, irony, satire, parody, playfulness, mockery, mirth, etc. All of them in some way or another have something to do with laughter even if it is merely 'inner' laughter." 


\section{Enter the Clown}

\section{Embodying Human Frailty}

The clown is by definition a curious figure. $\mathrm{He}^{6}$ operates on a different wavelength than that of the status quo. In the circus the clown stands out, because he does not fit in: amidst the splendour of trapeze artists, magicians and daring performances - that is, amongst the symbols of breathtaking human achievements - he represents another world, another side of humanity. With his red nose and over-sized shoes, his stumbling about and fooling around, he embodies the frailty and vulnerability of human life. His very presence relativizes the mighty and clever, unmasks them as mere mortals, in need of comfort and help. His colourful adornment and brightly painted face bring together joy but also tears; he integrates laughter and lament. In doing so, he transforms the circus arena into a more humane, liveable space (cf. Faber:1971:99).

The clown has the remarkable ability to connect to people in the borderline experiences of their lives. He teaches them to laugh at, and in, their experiences of liminality, even though it may often seem like no laughing matter at all. In a disarming manner he demonstrates their smallness, but also their potential for greatness in overcoming adversity. The clown embodies the good news that human beings can retain their humanness, even if they are stripped of everything, and when all else fails. After falling down, the clown always gets up and has the last laugh (Faber 1971:102).

If one applies this metaphor (which indicates identification with human frailty) to the person of the preacher, the theological paradigm of the incarnation comes to mind, and in conjunction with that, the paradigm of the indwelling of the Holy Spirit (inhabitatio spiritus sancti). Through Christ and his Spirit, God sides with the broken and vulnerable (cf. also 2.4 below). Preachers who take these paradigms seriously, live and preach in solidarity with those that God identifies with.

This implies that preachers view their congregations with new eyes, that they use a theological key if they wish to understand at least something of the congregational life, which is also a fully human life. It implies that they view theologically those who attend the worship service, i.e. people with whom God has been having a relationship for a long time, even before the preacher appeared on the scene; people for whom Christ died and was resurrected; people for whom God's grace therefore is enough - exactly because they are frail and vulnerable. It further implies that they regard those who sit in the church pews as human beings, rather than as religious clients whose interests must be dealt with, as well as possible (cf. Cilliers 2004:133). Karl Barth's comments (1964:96-97) to this effect speak of homiletical wisdom:

- The preacher must love his/her congregation, and be one with them. The basic attitude must be: these are my people and I want to share with them what God has given me. No matter how eloquent you may be, even if you are more articulate than angels, but without love, you are nothing...

- Because the preacher loves the congregation, he/she must live the life of the congergation, at their level. The preacher need not necessarily be the cleverest among them, or the town's fortune-teller who reveals people's thoughts, but the question that expresses their most profound thoughts must always be the concern of the preacher's heart.

- Preaching is not merely a clearer and more adequate explanation of the meaning of life, amidst other explanations - although this is not unimportant - but rather it places the

6 The masculine form is used because clowns are traditionally male; the implications of the metaphor are, however, meant to be inclusive. 
meaning of life, and especially also our experiences of frailty and transience, within the

light of God's revelation.

The fact that the clown (or preacher) embodies human frailty does not, however, mean that he (or she) is innocuous, or merely a figure whom you can laugh at and leave it at that. As mentioned already, the fact that the clown unmasks the vulnerability of human beings is not necessarily well received; on the contrary, it is often interpreted as disruptive and even subversive. It often evokes hostility.

\section{Disrupting the Powers}

The clown represents an alternative world-view - often unsettling to the dominant or conventional one. According to Cox, the clown "refuses to live inside this present reality. He senses another one. He defies the law of gravity, taunts the policeman, ridicules the other performers. Through him we catch a glimpse of another world impinging on this one, upsetting its rules and practices" (1969:150). One is reminded of Kolakowski's (1962:233) classic description:

The philosophy of the jester is a philosophy which in every epoch denounces as doubtful what appears as unshakable; it points out the contradictions in what seems evident and incontestable; it ridicules common sense into the absurd - in other words, it undertakes the daily toil of the jester's profession along with the inevitable risk of appearing ludicrous.

Whilst the figure of the clown reminds us of the transience of life, and points towards an alternative world-view, the image of the jester also offers another angle: it disempowers the powerful in a comic fashion. The court jester playing before the King implicitly proclaims a message and extends an invitation: that the King should become more of a jester; that he should relativize himself; that he should not take his own power so seriously that it becomes an eternal state of affairs, or worse, a tool to be misused. The image of the jester suggests reciprocal transference: the King relinquishes his power to the jester, and the jester his (foolish) wisdom to the King.

The jester's acts imply that the powers of this world are to be resisted, but not violently. Rather ethically, aesthetically, comically. For preachers this means: we should play the fool and so frustrate these powers. We should juxtapose and so jolt the systems. We should subvert and so shatter the status quo. The tool for doing this is not the sword (violence), but the word (and ultimately, the Word; cf. 2.3 below).

I believe that this reciprocal transference attains an acute meaning in our present South African context. We know what it means to grieve for change - to borrow the title from Arbuckle's well-known book. ${ }^{7}$ As a matter of fact, the proceedings of the Truth and Reconciliation Commission (TRC) could also be described as, inter alia, an institutional and therapeutic space in which national mourning could take place. Our theology does understand at least something of lament (cf. Ackermann 2001:15).

But we need also to embrace a theology of laughter. Even from renaissance times laughter was understood to offer new and surprising insights into reality. According to Bakhtin: 
The Renaissance conception of laughter can be roughly described as follows: Laughter has a deep philosophical meaning, it is one of the essential forms of the truth concerning the world as a whole, concerning history and man; it is a peculiar point of view relative to the world; the world is seen anew, no less (and perhaps more) profoundly than when seen from the serious standpoint. Therefore, laughter is just as admissible in great literature, posing universal problems, as seriousness. Certain essential aspects of the world are accessible only to laughter (1984:66).

In a world full of pain we need the liberation of laughter. As a matter of fact, what we need is not only grieving for change, but also clowning for change. Grieving and clowning are closer to one another than one tends to think; they are two sides of the same coin. Like laughter and tears they complement one another. Perhaps one could venture to say that the meaning of life is found exactly in the interaction between grieving and clowning (cf. also Kierkegaard 1959:631). Death is swallowed up in the comical cry:"Where is your victory? Where is your sting?" (cf. 1 Cor. 15:55). Meaning (life triumphing over death) is born out of an empty tomb. It is a laughing matter. In Eugene O'Neill's play, Lazarus Laughs, Lazarus emerges from the tomb with a bellow of laughter (as quoted in Wirt 1991:44). Meaninglessness is overcome by mirth.

At the cross it seems as though all joy has vanished, but: "Easter is an altogether different matter. Here indeed begins the laughter of the redeemed, the dancing of the liberated and the creative game of new, concrete concomitants of the liberty which has been opened for us, even if we still live under conditions with little cause for rejoicing” (Moltmann 1971:50).

Long calls for a renewed joy in preaching exactly because of this theology of Easter mirth, and states: "Because God in Christ has broken the power of sin and death, Christian congregations and their preachers are free to laugh at themselves, and they can also laugh at the empty gods of pride and greed. They can mock hell and dance on the grave of death and $\sin "(1989: 16)$.

Apartheid suffered from a lack of humour (Theron 1996:216). As a matter of fact, all oppressive systems and ideologies do, as they are characterized by pretentiousness, arrogance, fanaticism, intolerance and repression. Grieving changed the gravity and humourlessness of apartheid, and by the grace of God we also had a few people and preachers with a liberating laugh (Desmond Tutu comes to mind), but as a country in transition (liminality) we need that now more than ever. Humour not for the sake of being funny - realities such as poverty and xenophobia are no laughing matter - but in the sense as described above. We need preachers who subvert the status quo, who rock the systemic boat, who rattle the cages in which we have become so comfortable. We need preachers who point towards, and embody, the biblical alternative, that is, who understand something of the subversive character of biblical texts.

\section{Using subversive Language}

According to Murav (1992:49), the holy fools of history sought to make visible the image of God in its deeply scandalous form. Therefore they provoked a new kind of looking, a way of "seeing" as never before, so creating a crisis of recognition, a crisis of decision (Murav 1992:97). The comic vision represents an enriched and deepened way of looking at life: on the one hand, it enables one to become more objective in viewing reality; on the other, it frees you to view this reality (which includes your own) with compassion. The comic vision offers an optical way of life (habitus) that keeps its (ironical) distance from reality, but at the same time discerns "signs of transcendence", epiphanies of deeper dimensions even in the small things of life (Weyel 2007:209-211; cf. also Berger, 1998:241). 
One of the ways in which this could be achieved is through language, through words. The language structures (and art forms) that are most fitting for this endeavour would be irony, satire, juxtapositions, paradoxes, metaphor, collage, humour, contradictions, opposites, etc. - modes of language that often dance on the head of so-called logic. Through these language tools new worlds can be created. These language structures are, of course, no strangers to the vocabulary of faith - they can also be found in scripture, where the ultimate paradox of God's story and our story are presented as intrinsically intertwined (cf. Cilliers 2008:62-76).

The image of the clown reminds us that we cannot, and indeed dare not, remain silent in the face of the reality and brutality of the powers of destruction and death that dominate and enslave us. This is of paramount importance for a country, and sadly also church, that so often buy into the syndromes of denial and silence. ${ }^{8}$ These syndromes are typical of the conventional functioning of public life. In most public spheres we are required to adopt the language of equilibrium; the raw edges of suffering and chaos must be suppressed or denied in order to ensure "safety and security". This is particularly true in the political sphere, where denial seems to be an integral part of political strategy. Consequently, our speech corresponds with the "normalities" of a self-deceptive culture in which everything must be seen to be functional, and which may never depict frailty and brokenness. Language that upholds this culture of denial becomes mundane and unimaginative: it dare not criticize the raw reality of the status quo, dare not be revolutionary and dangerous (Cilliers 2007:158). More often than not we also preach in such a manner that we in fact endorse the status quo - which is about as bad as denying that there are systems and powers in place that enslave us.

The language of the clown stands in stark contrast to the language of denial. By ridiculing this denial, the clown speaks the truth. The language of the clown is not necessarily eloquent (although it could, of course, be described as exactly that!); for many it resembles the stammering of a fool. This is exactly what the holy fool in Dostoevsky's delightful short story ${ }^{9}$ experiences: "After my dream [of salvation JC] I lost the knack of putting things into words. At least, into the most necessary and important words. But never mind. I shall go on and I shall keep on talking, for I have indeed beheld it with my own eyes, though I cannot describe what I saw" (2001:285). Perhaps this is a fitting definition of preaching: at its best, it can only be a stammering in the light of the overwhelming grace of God.

The language of denial or stabilization needs to be disrupted by the gospel's rhetoric of vulnerable madness, by stuttering the "unspeakable meaning" of the vulnerable Word in the holy, nonsensical endeavour of preaching. This could indeed be a description of the calling of the preacher as holy fool: to unsettle normative discourse, to unmask and lampoon, to "re-structure" mental images (cf. Grözinger 2008:96).

And this is where the biblical accounts of God's alternatives, within the cul de sac of the impossible, come to the aid of the preacher. It is not incidental that the ironical twists that shift our minds, the juxtapositions that invite us to reconsider, the strange countertestimonies that have an iconoclastic and anti-ideological function can be found in the biblical texts (cf. also Brueggemann 1997:317-403).

$8 \quad$ This culture of denial has been illustrated by telling incidents on governmental level in the recent past. President Thabo Mbeki's expressed disbelief in the exclusive link between HIV and AIDS is well known. So also his persistent conviction that Zimbabwe "faces no crises", and most recently, his hesitation in speaking out about the xenophobic attacks in South Africa.

9 Dostoevsky, F 2001. The Dream of a Ridiculous Man: A Fantastic Story. In The Best Short Stories of Fyodor Dostoevsky. Trans. David Magarshack. New York: Modern Library. 263-285. 
Texts often serve as counter-testimonies or cross-examinations of our core beliefs. They more than often reveal sides or images of God that hardly fit in with conventional theological and sermonic language. They speak of the hiddenness, ambiguity and negativity of God. Often we choose not to preach on this, because we do not understand that we need these images of God, held in tension with others, if we are to make sense of reality with all its experiences of disorientation, chaos and death.

In preaching this Word, one is called to step back, allowing the Word to create its own paradoxical spaces within which people's paradigms might be shattered and shifted. Preachers cannot achieve this on their own. In this "powerlessness" of the preacher lies the power of the Word of God, and the God of the Word. Ultimately, the strange, subversive texts of the Bible reshape and reframe our God images.

\section{Representing a vulnerable God}

The image of the preacher as fool opens up vistas of a theology that take the vulnerability and weakness of God seriously. Behind the image of the preacher as jester lurks the image of Christ as jester, or clown. The symbol of Christ as clown has deep historical roots. It was known and understood by the early Christians, but seems to have faded away when the church became powerful, and its view of itself "moved from the ridiculous to the sublime" (Cox 1969:141). But, now that the church has moved into a secularized, post-Christian era, this symbol of the harlequinesque Christ, "his pathos, his weakness, his irony - all begin to make a strange kind of sense again" (Cox 1969:141).

Already in 1969 Harvey Cox thought that we need exactly this image of Christ and therefore also of preachers in a world surrounded and overwhelmed by powers of domination and violence and death. He asks a question, and then answers it:

But why a clown Christ in a century of tension and terror? The clown represents different things to different people. For some he is the handy butt of our own fears and insecurities. We can jeer at his clumsy failures because they did not happen to us. For some he shows what an absurd clod man really is, and he allows us on occasion to admit it. For others he reveals to us our stubborn human unwillingness to be encaged forever within the boundaries of physical laws and social proprieties. The clown is constantly defeated, tricked, humiliated, and tramped upon. He is infinitely vulnerable, but never finally defeated (1969:141).

In this last phrase lies a striking God image: infinitely vulnerable, but never finally defeated. The Word that is preached is vulnerable and fragile, it relies on flawed speech, and is open to misuse and abuse. But behind this vulnerable Word also stands a vulnerable God. He does not side with the powerful and mighty, but rather is "in a world full of injustice and enmity ... in a special way the God of the destitute, the poor and the wronged" (Belhar Confession, article 4).

Apartheid ideology operated with the certainty, the securocracy, of a God that was omnipotent and strong, and that acted according to the basic beliefs of the ideology (cf. Cilliers 2006:77f.). In a sense apartheid ideology had control over this God, had a "handle on the cross" (cf. Bosch 1979; 32). It was unashamedly selective in its God images.

But there are also other images of God in the Bible, unsettling counter-testimonies that we need to listen to. We need to learn that our theology is an (open, surprising, shocking, disturbing, comforting) event, not a stable, eternal structure. We need to be "wounded by theology, unhinged and uprooted by the blow it has delivered to my heart" (Caputo 2001:1). 
In a moving account the theologian Nancy Eiesland, herself being a disabled person, speaks of her epiphany in regard to the image of God:

I had waited for a mighty revelation of God. But my epiphany bore little resemblance to the God I was expecting or the God of my dreams. I saw God in a sip-puff wheelchair, that is, the chair used mostly by quadriplegics enabling them to maneuver by blowing and sucking on a strawlike device. Not an omnipotent, self-sufficient God, but neither a pitiable, suffering servant. In this moment, I beheld God as a survivor, unpitying and forthright (1994:89).

We need to understand anew in South Africa that God sides with the broken and downtrodden, the poor, the suffering, and those being displaced by xenophobia. Preachers who take clowning for change seriously, who act as court jesters before the King (those in power), should not only subvert the King to become like the jester, but to become like the God lurking behind the jester, the God that is found in the vicinity of the marginalized. It is preaching that proclaims, and embodies, God's solidarity with broken humanity.

Because that is who, and how, God is. Nowhere in the Bible is God portrayed as a king only dealing with an issue at some distance. He does not even send a subordinate to cope with the problem, and he does not issue an edict designed to alleviate the suffering. God does not view suffering from the outside, as through a window. He sees it from the inside, relates to it internally, enters into it fully and makes it his own. In this way He overcomes it (cf. Fretheim 1984:128).

God sides in solidarity with suffering humanity. He is a vulnerable, broken God. Preaching about this God might indeed seem foolish to many, might sound like silly stuttering. But this stuttering is all about the wisdom and power of God (cf. 1 Corinthians $1: 18-30)$.

\section{BIBLIOGRAPHY}

Ackermann, D 2001. Tamar's cry: re-reading an ancient text in the midst of an HIV/AIDS pandemic. Johannesburg: EFSA.

Arbuckle, GA 1991. Grieving for change. A spirituality for refounding communities. Strand, London: Cassell Publishers Limited.

Bakhtin, M 1984. Rabelais and His World. Trans. by Helene Iswolsky. Bloomington: Indiana University Press.

Barth, K 1964. Prayer and preaching. London: SCM Press Ltd.

Berger, PL 1998. Erlösendes Lachen. Das komische in der menschlichen Erfahrung. Berlin/New York: Walter de Gruyter.

Bosch, D 1979. A Spirituality of the Road. Scottdale, Pennsylvania: Herald Press.

Brueggemann, W 1997. Theology of the Old Testament. Testimony, Dispute, Advocacy. Minneapolis: Fortress Press.

Campbell, C 2008. The Foolishness of Preaching. Ethical Reflections. Paper delivered at the eighth international conference of the Societas Homiletica, held in Copenhagen, Denmark, 19-25 June 2008. 1-19.

Caputo, JD 2001. The Weakness of God. A Theology of the Event. Bloomington and Indianapolis: Indiana University Press.

Cilliers, JH 2004. The Living voice of the Gospel. Revisiting the basic principles of preaching. Stellenbosch: Sun Press. 
Cilliers, JH 2006. God for us? An analysis and evaluation of Dutch Reformed preaching during the Apartheid years. Stellenbosch: Sun Press.

Cilliers, JH 2007. Preaching as language of hope in a context of HIV and AIDS. Preaching as a Language of Hope. Studia Homiletica 6, Ed. Cas Vos, Lucy L Hogan and Johan H Cilliers. Pretoria: Protea Book House. 155-176.

Cilliers, JH 2008. Skrifbeskouing en Skrifhantering: perspektiewe op 'n hermeneutiek van verwagting. Verbum et Ecclesia. Volume 29 (1) 2008. 62-76.

Cox, H 1969. The Feast of Fools. A Theological Essay on Festivity and Fantasy. London: Harper Colophon Books.

Dostoevsky, F 2001. The Dream of a Ridiculous Man: A Fantastic Story. In The Best Short Stories of Fyodor Dostoevsky. Trans. David Magarshack. New York: Modern Library. 263-285.

Eiesland, NL 1994. The Disabled God. Towards a Liberatory Theology of Disability. Nashville: Abingdon Press.

Faber, H 1971. De pastor in het moderne zieken huis. Assen: Van Gorcum en Comp.

Fretheim, TE 1984. The Suffering of God. Philadelphia: Fortress Press.

Grözinger, A 2008. Homiletik. Lehrbuch Praktische Theologie. Band 2. München: Gütersloher Verlagshaus.

Kierkegaard, S 1959. Philosophische Brosamen und Unwissenschaftliche Nachschrift. Unter Mitwurking von Niels Thulstrup und der Kopenhagener KierkegaardGesellschaft herausgegeben von Hermann Diem und Walter Rest. Köln und Olten: Bei Jakob Hegner.

Kolakowski, L 1962. The Priest and the Jester. Dissent 9/3, Summer 1962.

Long, TG 1989. The Witness of Preaching. Louisville, Kentucky: Westminster/John Knox Press.

Moltmann, J 1971. Theology and Joy. London: SCM Press Ltd.

Murav, H 1992. Holy Foolishness: Dostoevsky's Novels and the Poetics of Cultural Critique. Stanford, Cal.: Stanford University Press.

Noordmans, O 1980. Verzamelde Werken 8. Kampen: Kok.

Theron, PF 1996. Liberating humour. Calvinism and the comic vision. In Studies in Reformed Theology Volume 1, 208-224.

Weyel, B 2007. Predigt und Alltagskunst. Wilhelm Genazino und der poetische Blick auf das Leben. In Religion - Ästhetik-Medien. Band 2. Ästhetik und Religion. Interdisziplinäre Beiträge zur Identität und Differenz von ästhetischer und religiöser Erfahrung. Hrsg. Gräb, W; Hermann, J; Kulbarsch, L; Metelmann, J; Weyel, B. Frankfurt am Main: Peter Lang.

Wirt, SE 1991. The Heresy of the Serious. Christianity Today 35 (1991). 